\title{
A Study to Evaluate the Effectiveness of Planned Teaching Programme Regarding Knowledge on Care of Old Age Health Problems Among Family Members of Simikeri Village (Tal \& Dist) Bagalkot
}

\author{
Gundurao Chilapur ${ }^{1}$, Chetan S Patali*2 and Suvarna S Pinnapati ${ }^{3}$ \\ ${ }^{1}$ Phd Scholar of Rajiv Gandhi University of Health Sciences, India \\ ${ }^{2}$ Principal, Dhanush Institute of Nursing Sciences, India \\ ${ }^{3}$ Suvarna S Pinnapati. Vice-Principal, Dhanush Institute of Nursing Sciences, India
}

Submission: June 21, 2018; Published: July 03, 2018

*Corresponding author: Chetan S Patali, Principal, Dhanush Institute of Nursing Sciences, Bagalkot, India, Email: chetan1309@gmail.com

Abstract

Background of the study: Ageing is a universal phenomenon old age is not in itself a disease, but is a normal part of the human life span. Ageing is normal, universal, progressive, irreversible process. It is an inevitable physiological phenomenon. The human life span follows a recognized pattern birth to death. Then there is a gradual deterioration in physical and mental abilities. As the ageing process progress mental capabilities such as memory and physical abilities further deteriorate. As the individual develops and matures socially and physically from birth through adolescence and after the age of 30years additional changes occur that reflects normal decline in all organ systems, then it is called senescence. This happens gradually throughout the body system reducing the viability of different body systems and increasing their vulnerability to disease.

\section{Objectives}

a. To assess the knowledge regarding old age health problems among the family members.

b. To evaluate the effectiveness of planned teaching programme regarding old age health problems among the family members.

c. To find out the association between pretest knowledge regarding old age health problems with selected socio demographic variables.

Conceptual Frame Work: For the present study the conceptual frame work is used based on General systems theory by Ludwig Von Bertanlanffy.

Method: This was quasi experimental study with 80 subjects were selected through simple random sampling technique. One group pre test post test design was used. Data was collected by means of structured interview schedule which was divided in to 2 sections (socio-demographic data and knowledge regarding care of selected old age health problems among family members). The reliability of the tool was established by Split Half method. The Karl Pearson's coefficient of correlation $r=0.7999$ Planned teaching programme on care of selected old age health problems was developed. After content validity of the tool was established by six experts. Data was analyzed by using descriptive and inferential statistical in terms of frequency, percentage, mean, standard deviation, student' $t$ ' test values.

Result: It was proved that there was increase in the knowledge level of family members after implementing planned teaching programme, thus planned teaching programme on care of selected old age health problems among family members was effective. Out of 80 subjects 42 $(52.50 \%)$ of subjects had inadequate, $31(38.75 \%)$ had satisfactory and $7(8.75 \%)$ had adequate knowledge regarding care of selected old age health problems before teaching programme (pre test). However after teaching programme (post test) about 21(26.25\%) subjects had adequate knowledge and $37(46.25 \%)$ satisfactory knowledge, where as $22(27.50 \%)$ had inadequate knowledge regarding care of selected old age health problems.

Conclusion: The study proved that planned teaching programme on care of selected old age health problems among family members was scientific, logical and cost effective strategy.

Keywords: Family members; Care of selected old age health problems; Planned teaching programme 


\section{Introduction}

You must be humble enough to love, so that you will touch the hearts of others and make them think of you with love. It is better to be forgotten entirely than to be remembered without love [1]. According to the United Nations the word old age is defined an age person as one who is 60years and above. Generally people above age of 60years are considered as senior citizens. Indian people between 60-75years are categorized as "young old" between 75-85years as "old-old" and people above the age of 85years are classified as "very old" or inferno. There is marked difference in the health needs of these age groups [46]. Ageing is a universal phenomenon old age is not in itself a disease, but is a normal part of the human life span. Ageing is normal, universal, progressive, irreversible process. It is an inevitable physiological phenomenon. The human life span follows a recognized pattern birth to death. Then there is a gradual deteriorisation in physical and mental abilities. As the ageing process progress mental capabilities such as memory and physical abilities further deteriorate [1]. Most of the care of dependent older people in the community is carried out by families in the home of older person. Old age is certainly accompanied by problems for a significant number of elderly people and care of elderly people is largely concerned with assessing these problems and their compensating for them or participating in the process of helping the elderly person to overcome them and regain a degree of independence. The increasing population of older people has sought the attention of world community. Emphasis is given on healthy and active ageing. It implies being holistically fit, being mobile, coping well with various living activities. It is very important to take care of old people when they are not well $[2,3]$. Nearly $72 \%$ of elderly live in rural and half of these are below poverty line. The remaining $28 \%$ of elderly live in urban areas. Further, about $90 \%$ of old person in India, are from unorganized sector. Around $10 \%$ of elderly belong to organized sector that have access to some distinct benefits like service pensions and health care facilities in the shape of CGHS, etc. The implication of ageing populations is earmark lot of budget to deal with their needs and problems. It is also adds on to dependent population in India [4-6].

\section{Need for the Study}

The word "aged" is relative depending upon the society. The term "Graying of Nations." "Aging of Nations" and demographic transition of "Pyramid to Pillar" are the concerns voiced all over the world. The word "geriatrics" was coined by Naseher in 1914 and, is derived from Greek word gerus \& iatrea, which means old age and treatment respectively [7]. Ageing is a universal phenomenon old age is not in itself a disease but is a normal part of the human life span. Ageing is normal universal progressive irreversible process. It is an inevitable physiological phenomenon the human life span follows a recognized pattern from birth to death there is a gradual deterioration in physical and mental capabilities, such as memory and physical abilities further deteriorate [1]. The study conducted on health problem among the aged persons of 60years at rural area of Calcutta. The result reveals that, main health related problems were (45.7\%) hypertension, (47.8\%) diabetes mellitus, and (54.3\%) arthritis [8].

\section{Materials and Methods}

\section{Objectives of the Study}

a) To assess the knowledge regarding old age health problems among the family members.

b) To evaluate the effectiveness of planned teaching programme regarding old age health problems among the family members.

c) To find out the association between pretest knowledge regarding old age health problems with selected socio demographic variables.

\section{Operational Definitions}

A. Evaluation: In this study evaluation refers to the process used to signify differences between pre \& post test scores, of family members regarding care of old age person.

B. Effectiveness: In this study effectiveness refers to the significant differences in the pre \& post test knowledge scores on selected aspect of care of old age health problems among family members.

C. Planned Teaching Programme: In this study planned teaching programme refers to a planned health education regarding knowledge on care of selected old age health problems such as hypertension, arthritis, cataract \& diabetic mellitus among family members, developed by investigator.

D. Knowledge: In this study knowledge refers to the correct responses given by family members about care of old age health problems.

E. Old Age People: In this study, old age people refer to persons who are aged 60 years \& above, of both sex.

F. Selected Health Problems: In this study selected health problems refers to the health problems commonly affecting to the old age people, like Hypertension, Arthritis, Cataract and Diabetes mellitus.

\section{Assumptions}

a. The family members of simikeri village have some knowledge regarding care of the old age health problems.

b. There is significant association between pre \& post test knowledge score of respondent regarding care of old age health problems among family members.

c. The result of the study will help to take care of the old age health problems by family members.

\section{Hypothesis:}

$\mathrm{H}_{1}$ : The mean post test knowledge score of family members exposed to planned teaching programme on care of age health 
problems will be significantly higher than their mean pre test score.

$\mathrm{H}_{2}$ : A significant association will be found between the knowledge of family members regarding care of old age health problems with selected socio-demographic variables [9].

\section{Methodology}

\section{Population}

Population includes all possible elements that could be included in research [10].

The target population of the study is the family members of old age persons of Simikeri village (Tal \& Dist) Bagalkot.

The accessible population of the study is the family members of old age persons of Simikeri village (Tal \& Dist) Bagalkot.

\section{Sample}

Sample is a small portion of the population selected for observation and proper analysis. 40 The sample for the present study composed of 80 family members of old age persons of Simikeri village (Tal \& Dist) Bagalkot [11].

\section{Sampling Technique}

Sampling technique is the procedure, which the researcher adopts in selecting the subjects for the study.1

In view of the objectives of the study simple random sampling was used.

\section{Sampling Criteria}

\section{Inclusion Criteria}

a. The family members who are willing to participate in study.

b. The family members who are present at the time of data collection.

\section{Exclusion Criteria}

a. The family members who are not willing to participate in study.

b. The family members who do not know English or Kannada.

c. The family members who are sick.

\section{Results}

A. Age: The following diagram represents the percentage distribution of study subjects by age groups. Out of 80 subjects, $48.75 \%$ of the subjects belong to20-29 years, followed by $32.50 \%$ in the age group of $30-39$ years, and $18.75 \%$ in the age of 40years above (Figures $1 \& 2$ ).

B. Marital Status: The following diagram represents the percentage distribution of study subjects by marital status.
66.25\% were married and $33.75 \%$ were un-married (Figure $3)$.

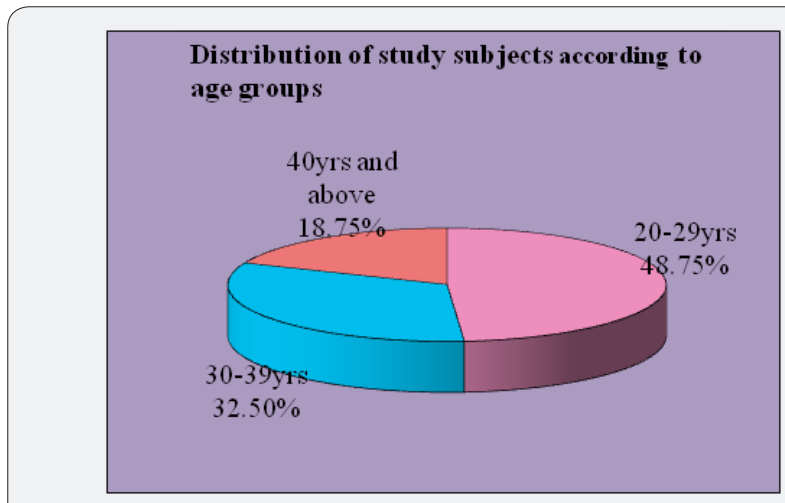

Figure 1: Pie diagram depicting distribution of study subjects according to age.

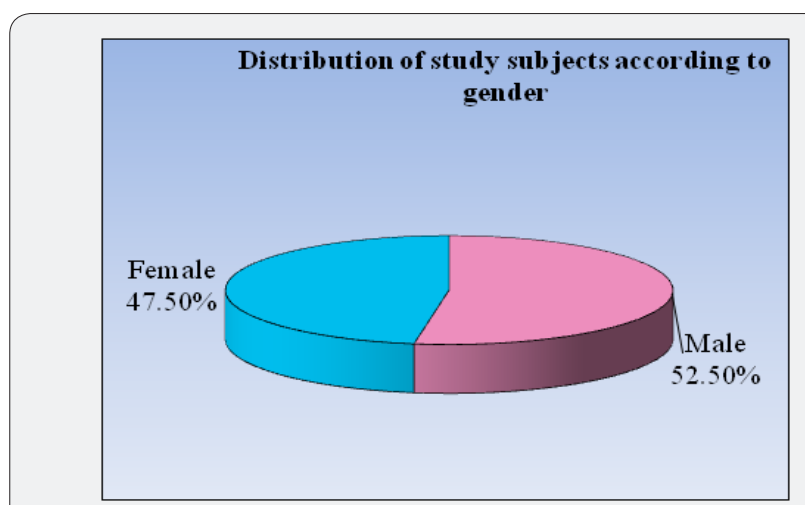

Figure 2: Pie diagram depicting distribution of study subjects according to gender.

Gender: $52.50 \%$ of the subjects were males and $47.50 \%$ were females.

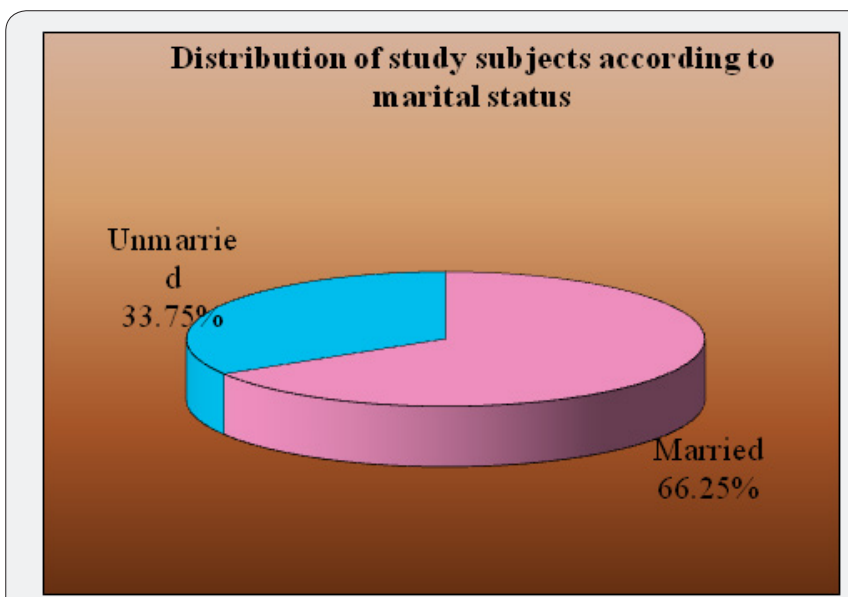

Figure 3: Pie diagram depicting distribution of study subjects according to marital status.

C. Religion: The following diagram represents the percentage distribution of study subjects by religion. Majority $46.25 \%$ of the samples were Hindus, $21.25 \%$ of the samples were Muslims, $15.00 \%$ of the samples were Christians, and $17.50 \%$ of the samples were others (Figure 4 ). 


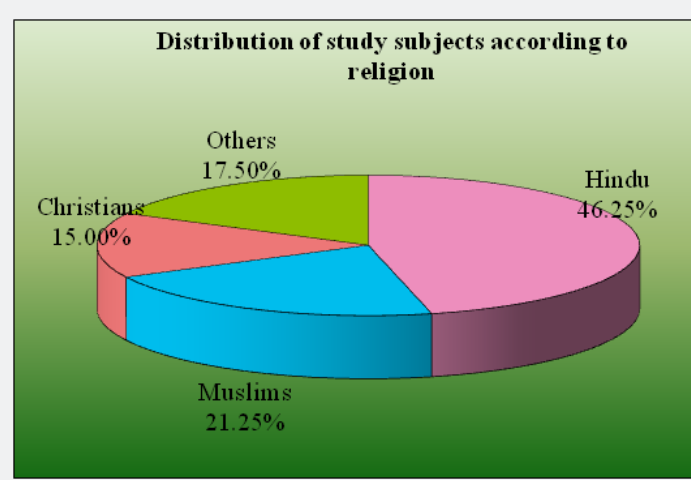

Figure 4: Pie diagram depicting of study subjects according to religion.

D. Educational Status: The following diagram represents the percentage distribution of study subjects by educational status. Out of 80 subjects, $41.25 \%$ subjects had no formal education, $35.00 \%$ up to Primary level, $16.25 \%$ had Secondary level, and remaining $7.50 \%$ had PUC \& above level education (Figure 5).

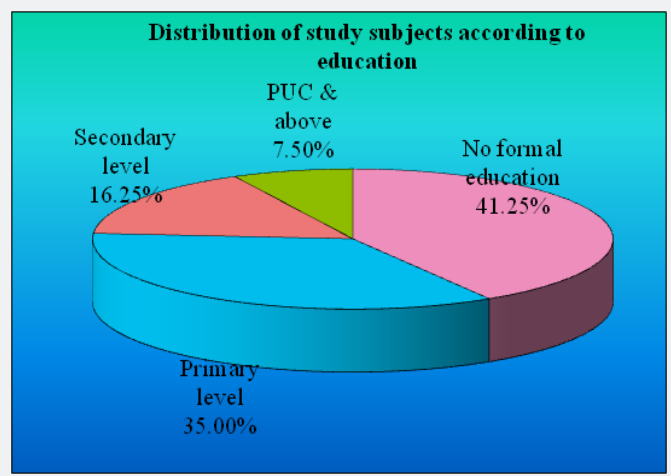

Figure 5: Pie diagram depicting of study subjects according to education.

E. Occupation: Majority $47.50 \%$ of the samples were agricultures, $18.75 \%$ were doing collie, $15.00 \%$ were private employees, $10.00 \%$ had government job, while $8.75 \%$ were with business (Figure 6).

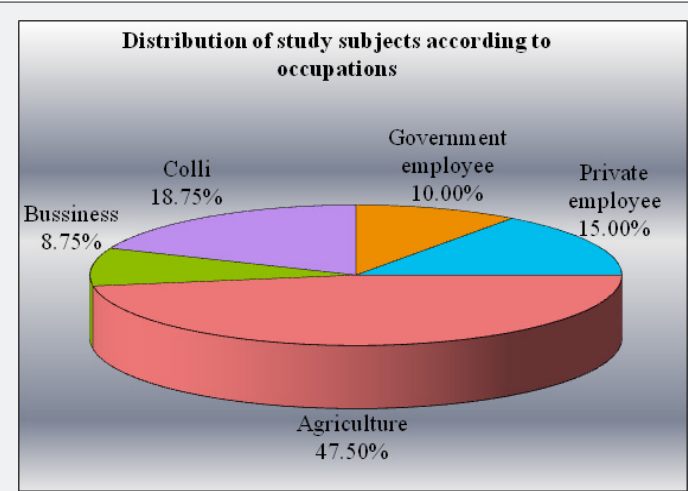

Figure 6: Pie diagram depicting distribution of study subjects according to occupation.

F. Types of Family: $71.25 \%$ were belongs to joint families while $28.75 \%$ belonged to nuclear family (Figure 7).

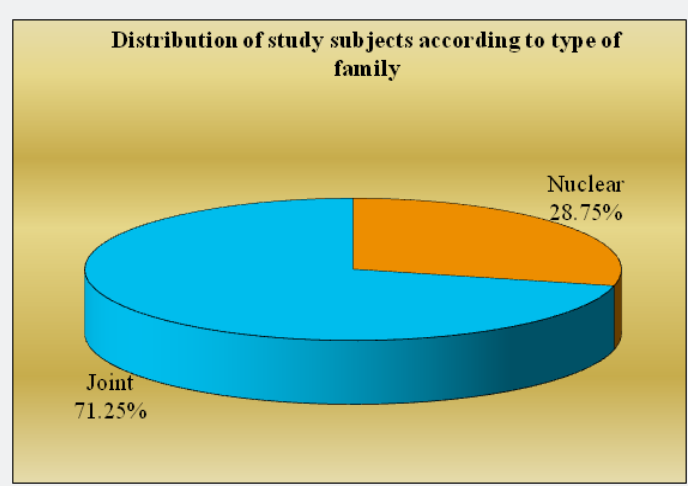

Figure 7: Pie diagram depicting distribution of study subjects according to type of family.

G. Income: $48.75 \%$ of the sample had an income between Rs 3000-5000, 26.25\% had between Rs7001-9000, 13.75\% were of Rs5001-7000 and 11.25\% had Rs 9001 \& above (Figure 8).

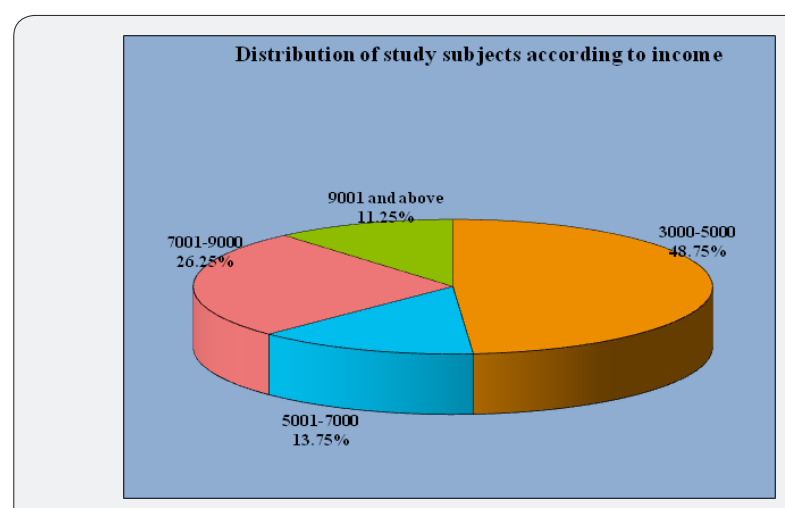

Figure 8: Pie diagram depicting distribution of study subjects according to income.

H. Relationship with the old Age Person: The following diagram shows relationship with the old age person $30.00 \%$ were son, $26.25 \%$ were wife, $23.75 \%$ were husband, $15.00 \%$ were daughter and $5.00 \%$ of others $[12,13]$ (Figure 9).

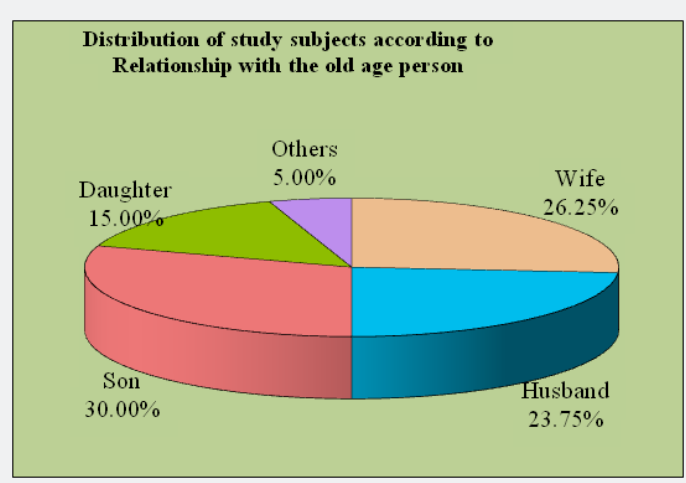

Figure 9: Pie diagram depicting distribution of study subjects according to relationship with the old age person.

\section{Assessment of Pretest and Post Test Knowledge Level}

Level of Knowledge: Table 1 represents that, out of 80 subjects $31(38.75 \%)$ had satisfactory knowledge, 42(52.50\%) had 
inadequate and only 7(8.75\%) subjects had adequate knowledge before implementation of teaching programme (pre test). However after teaching programme (post test) about 21(26.25\%) subjects had adequate knowledge and 37(46.25\%) satisfactory knowledge, where as $22(27.50 \%)$ had inadequate knowledge. The above findings states that "Research hypothesis H1: There is significant difference in the knowledge of family members regarding care of selected old age health problems before and after administration of planned teaching programme" as stated by the investigator earlier was accepted. The area wise pre test and post test knowledge percentage given in the above Table 2 clearly and the change in percentage is the effectiveness of the planned teaching programme (Figure 10).

Table 1: Distribution of study subjects according to levels of knowledge in pre and post test.

\begin{tabular}{|c|c|c|c|c|}
\hline \multirow{2}{*}{ Level of knowledge } & \multicolumn{2}{|c|}{ Pre test } & \multicolumn{2}{c|}{ Post test } \\
\cline { 2 - 5 } & No of respondents & Percentage & No of respondents & 21 \\
\hline Adequate & 07 & 8.75 & 37 & 46.25 \\
\hline Satisfactory & 31 & 38.75 & 22 & 27.50 \\
\hline Inadequate & 42 & 52.50 & 80 & 100.00 \\
\hline Total & 80 & 100.00 & 25 & \\
\hline
\end{tabular}

Table 2: Percentage of change of knowledge and its dimensions between pre and post test.

\begin{tabular}{|c|c|c|c|c|}
\hline Variable & No of items & Pre test (\%) & Post test (\%) & Change in \% \\
\hline Hypertension & 10 & 51.75 & 62.13 & 10.38 \\
\hline Diabetic mellitus & 10 & 43.50 & 63.50 & 20.00 \\
\hline Cataract & 10 & 47.75 & 63.25 & 15.50 \\
\hline Arthritis & 10 & 48.38 & 65.63 & 17.25 \\
\hline Total knowledge & 40 & 47.84 & 63.63 & 15.78 \\
\hline
\end{tabular}

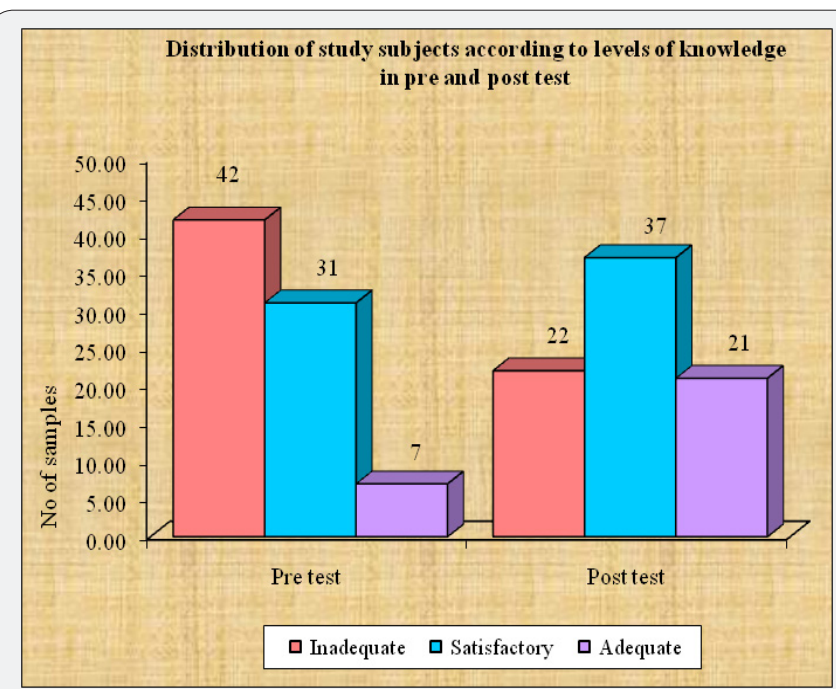

Figure 10: Bar diagram depicting distribution of study subjects according to levels of knowledge in pre and post test
From the results of above Table 3, we clearly seen or observed that, the pre test and post test total knowledge scores are found to be statistically significant $(\mathrm{t}=-7.4832, \mathrm{P}=0.0000)$. It means that the post test knowledge scores $(63.63 \pm 16.04)$ is higher than pre test scores (47.84 \pm 11.95$)$. Similarly the dimension like knowledge about hypertension post test scores are higher $(62.15 \pm 21.97)$ as compared to $(51.75 \pm 18.6)$ and found to be statistically significant $(\mathrm{t}=-3.3760, \mathrm{P}=0.0011)$, the knowledge about diabetic mellitus in the post test scores are higher $(63.50 \pm 20.63)$ as compared to $(43.50 \pm 16.54)$ and found to be statistically significant $(\mathrm{t}=$ $-7.0131, \mathrm{P}=0.0000)$, the knowledge about cataract the post test scores are higher $(63.25 \pm 19.21)$ as compared to $(47.75 \pm 16.99)$ and found to be statistically significant $(\mathrm{t}=-6.0429, \mathrm{P}=0.0000)$ and the knowledge about arthritis the post test scores are higher $(65.62 \pm 21.63)$ as compared to $(48.37 \pm 17.24)$ and found to be statistically significant $(t=-5.5527, P=0.0000)$. In other words the post test scores of total knowledge and its dimensions are higher than the pre test scores [14,15].

Table 3: Comparison of pre and post test knowledge and its dimensions scores by paired t-test.

\begin{tabular}{|c|c|c|c|c|c|c|c|}
\hline Variable & Test & Mean & Std. Dv. & Mean diff. & SD diff. & Paired t-value & p-value \\
\hline \multirow[t]{2}{*}{ Hypertension } & Pre-test & 51.7500 & 18.0558 & & & & \\
\hline & Post test & 62.1250 & 21.9720 & -10.3750 & 27.4873 & -3.3760 & $0.0011^{* *}$ \\
\hline \multirow[t]{2}{*}{$\begin{array}{l}\text { Diabetic } \\
\text { mellitus }\end{array}$} & Pre-test & 43.5000 & 16.5430 & & & & \\
\hline & Post test & 63.5000 & 20.6293 & -20.0000 & 25.5075 & -7.0131 & $0.0000^{* * *}$ \\
\hline \multirow[t]{2}{*}{ Cataract } & Pre-test & 47.7500 & 16.9866 & & & & \\
\hline & Post test & 63.2500 & 19.2107 & -15.5000 & 22.9419 & -6.0429 & $0.0000^{* * *}$ \\
\hline
\end{tabular}




\begin{tabular}{|c|c|c|c|c|c|c|c|}
\hline Arthritis & Pre-test & 48.3750 & 17.2431 & & & \\
\hline & Post test & 65.6250 & 21.6324 & -17.2500 & 27.7865 & -5.5527 & $0.0000^{* * *}$ \\
\hline Total knowledge & Pre-test & 47.8438 & 11.9515 & & & & \\
\hline & Post test & 63.6250 & 16.0394 & -15.7813 & 18.8624 & -7.4832 & $0.0000^{* * *}$ \\
\hline
\end{tabular}

\section{Discussion}

a. Majority $48.75 \%$ of subjects were between $20-29$ years of age, $32.50 \%$ were between $30-39$ years of age and $18.75 \%$ were above 40 years of age.

b. Majority $52.50 \%$ of the subjects were males and rest $47.50 \%$ were females.

c. Majority $66.25 \%$ of the subjects were married and remaining $33.75 \%$ were unmarried.

d. Majority $46.25 \%$ of samples were Hindus, $21.25 \%$ were Muslims, $17.50 \%$ were others and $15 \%$ were Christians [16].

e. Majority $41.25 \%$ had no formal education, 35\% had primary education, $16.25 \%$ had secondary education and $7.50 \%$ had PUC and above level of education status.

f. Majority $47.50 \%$ were having Agricultures, $18.75 \%$ had Collies, 15\% were Private employee, 10\% had Government employee and $8.75 \%$ were Business.

g. Majority $71.25 \%$ were Joint family and $28.75 \%$ of the subjects were from nuclear family.

h. Majority $48.75 \%$ had Rs $3000-5000 /$ month, $26.25 \%$ were Rs 7001-9000/month, $13.75 \%$ had Rs 5001-7000 PM and $11.25 \%$ had Rs 9001 and more income per month.

i. Majority $30 \%$ of the subjects were son, of old age person $26.25 \%$ were wife, $23.75 \%$ were husbands, $15 \%$ were daughters and rest $5 \%$ were others [17].

The first objective was to assess the existing knowledge regarding old age health problems among the family members. The result of the study clearly indicated that out of 80 subjects $42(52.50 \%)$ of subjects had inadequate knowledge, 31(38.75\%) subjects had satisfactory and only $7(8.75 \%)$ had adequate knowledge regarding care of selected old age health problems before planned teaching programme (pre test). However after planned teaching programme (post test) about 37(46.25\%) subjects had satisfactory knowledge, $22(27.50 \%)$ had inadequate and $21(26.25 \%)$ had adequate knowledge regarding care of selected old age health problems [18-20].

\section{Recommendations}

The study can be replicated on larger sample in different villages.

a. A comparative study can be conducted between urban and rural family members regarding care of selected old age health problems. b. A study can be conducted with to evaluate the effectiveness of video assisted teaching module regarding care of old age health problems among family members.

c. A study can be conducted to assess the knowledge and practice regarding care of old age health problems among health worker working at old age homes.

d. A study can be conducted to assess the knowledge, attitude \& practice regarding care of selected old age health problems among family members.

\section{References}

1. Abdellah FG (1986) Better patient care through Nursing research. Mc Milan publishing Co. New York, USA.

2. Alba Aguado, Flora Lopez, Sonia Miravet, Pilar Oriol, M Isabel Fuentes, et al. (2009) Hypertension in the very old; prevalence, awareness, treatment and control: a cross-sectional population-based study in a Spanish municipality. BMC Geriatric 9: 16.

3. Alligood MR, Tomey A (2003) Nursing theories; Utilization and application. ( $2^{\text {nd }}$ edn) St. Louis: Mosby, Nursing Science Quarterly, USA, 16(1): 93-94.

4. BT Basavantappa. A text book of "Nursing Research" First edition, Jayapee Brothers Medical Publishers (P) Ltd, B.3 EMCA House, 23/23 B Ansari Road, Daryaganj Post Box 7193 New Delhi 110002. India.

5. Bekibele CO, Gureje O (2008) Impact of self reported visual impairment on quality of life in the Ibadan study of aging. Br J Ophthalmol 92(5): 612-615.

6. Bhatia S, Swami HM, Thakur JS, Bhatia V (2007) A study of health problems and Loneliness among the elderly in Chandigarh. Indian J Community Med 32(4): 255-258.

7. Carnethon MR, Yan L, Greenland P, Garside DB, Dyer AR, et al. (2008) Resting heart rate in middle age and diabetes development in older age. Diabetes Care 31(2): 335-339.

8. Carol A Miller (1999) Nursing care of older adults and practice $\left(3^{\text {rd }}\right.$ Edn.), Lippincott Williams Wilkins, 227, East Washington Square, Phidelphia, USA.

9. Catherine ward Griffin (2004) Nurses as caregivers of elderly relatives. Canadian Journal of Nursing research 36(1): 92-114

10. Chen YM, Chen LK, Lan JL, Chen DY (2009) Geriatric syndromes in elderly patients with rheumatoid arthritis. Rheumatology(Oxford) 48(10): 1261-1264.

11. Chou KL, Chi I (2005) Prevalence of depression among elderly Chinese with diabetes. Int J Geriatr Psychiatry 20(6): 570-575.

12. Creasia JL, Parker B (1991) Conceptual foundations of professional practice (1 $1^{\text {st }}$ Edn.), Mosby, USA pp.679.

13. Dane FC (1990) Research Methods ( $1^{\text {st }}$ Edn.), Brooks Kale Publishing Company, California, USA.

14. Dey AB, Soneja S, Nagarkar KM, Jhingan HP (2001) Evaluation of the health and functional status of older Indians as a prelude to the development of a health programme. Natl Med J India 14(3): 135-138. 
15. Frank A Sloan, Daniel W Belsky, Idrissa A Boly (2008) Prevalence of major eye diseases among US Civil war veterans. Arch opthalmol 126(2): 246-250.

16. Gotta M, Seymour J, Bellamy G, Clark D, Ahmedzai S (2004) Older people's views about home as a place of care at the end of life. Palliative Medicine 18(5): 460-467

17. Greenberger $\mathrm{H}$, Litwin $\mathrm{H}$ (2003) Can burdened care givers be effective facilitators of elder care- reciepient health care. J Adv Nurs 41(4): 332 341

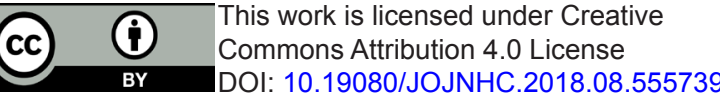

18. Gupta HL, Yadav M, Sundarka MK, Talwar V, Saini M, et al. (2002) A study of prevalence of health problems in asymptomatic elderly individuals in Delhi. J Assoc physicians India 50: 792-795.

19. H Agarwal, S Baweja, KR Haldiya, A Mathur (2005) Prevelence of hypertension in elderly population of desert region of Rajastan. Journal of the Indian Academy of Geriatrics 1: 14-17.

20. WHO (2011) National Institute of Aging. USA, p. 32.

\section{Your next submission with Juniper Publishers will reach you the below assets}

- Quality Editorial service

- Swift Peer Review

- Reprints availability

- E-prints Service

- Manuscript Podcast for convenient understanding

- Global attainment for your research

- Manuscript accessibility in different formats

( Pdf, E-pub, Full Text, Audio)

- Unceasing customer service

Track the below URL for one-step submission https://juniperpublishers.com/online-submission.php 